\title{
Fault tolerant control concepts applied to anesthesia
}

\section{Doctoral Thesis}

Author(s):

Frei, Christian Walter

Publication date:

2000

Permanent link:

https://doi.org/10.3929/ethz-a-003890286

Rights / license:

In Copyright - Non-Commercial Use Permitted 
Diss. ETH No. 13599

\title{
Fault Tolerant Control Concepts Applied to Anesthesia
}

\author{
A dissertation submitted to the \\ Swiss Federal Institute of Technology (ETH) \\ Zurich
}

for the degree of

Doctor of Technical Sciences

\author{
presented by \\ Christian Walter Frei \\ MSEE Northwestern University, Dipl. NDS ETHZ \\ born July 171967 \\ citizen of Rietheim, AG
}

accepted on the recommendation of

Prof. Dr. A.H. Glattfelder, examiner

Prof. Dr. P. Niederer, co-examiner

Prof. Dr. A.M. Zbinden, co-examiner

Prof. Dr. M. Blanke, co-examiner

April, 2000 


\section{Summary}

The first application of automatic control to a physiological variable during general anesthesia was reported in 1949. Since then a lot of research has been devoted to this topic. Still, today there is no commercial anesthesia system available with the patient in a feedback loop. One reason for this is that research has mainly been focused on controller design. Important aspects of clinical practice such as the treatment of measurement artifacts and faults have only marginally been addressed. In this thesis exactly such problems which are usually tacitly neglected but which are of great relevance are addressed. We are referring to these aspects as supervisory functions.

Before addressing these supervisor functions some foundations are established. This involves in the first place a hard- and software research platform that allows to implement and test control algorithms as well as the supervisory functions in the operating theater. It is our view that fault handling must start with the design of a system. Special attention is therefore paid to the selection of the platform components and the software design. The software structure is built with special emphasis on extendibility. A second foundational building block is a mathematical model which describes the dynamic relationship between vaporizer concentrations and surgical stimulations on the input side and the inspiratory and endtidal Isoflurane concentration as well as mean arterial pressure (MAP) on the output side. A thorough review of the physiological background is followed by a step by step development of the model equations. Modeling is finalized with the identification of the system parameters and validation experiments.

Since the design of control algorithms is not the main focus, controllers are taken form a thesis by Marco Derighetti. They are refined for broader applicability where necessary. The result of extensive clinical validations of an observer based state feedback (OBSF) controller for the endtidal Isoflurane concentration and an OBSF with endtidal overrides for MAP are presented. In view of the limited ability of this MAP controller to compensate heavy disturbances a control scheme based on disturbance anticipation is suggested.

For the supervisor functions first a structure is suggested which allows to allocate all functions postulated in literature. A selection of these is developed in more detail. First, an elegant strategy to handle measurement artifacts in the framework of OBSF controller is proposed. It is based on a nonlinear modification of the output injection gain. The stability of this algorithm is proved and recordings of several successfully suppressed artifacts are shown. A large part of the thesis is then dedicated to fault tolerant control (FTC). Following a sequential design procedure developed by Prof. M. Blanke a strategy for handling the most critical faults in the system is obtained. In this context the concept of recoverability for linear time invariant (LTI) systems is developed. 
This concept is utilized to analyze to what degree the functionality of a faulty system may be recovered in case of a fault. Finally, a man machine interface (MMI) is designed. Aspects of $\mathrm{MMI}$ are important in this context since a well designed MMI increases operational safety.

The main contribution of this thesis is to show that mathematical process models are a useful tool in dealing with faults also in a biomedical environment. 


\section{Zusammenfassung}

Seit der ersten automatischen Regelung einer physiologischen Messgrösse während einer Generalanästhesie im Jahre 1949 wurde eine Vielzahl von wissenschaftlichen Arbeiten in diesem Gebiet publiziert. Trotzdem existiert bis heute kein kommerzielles Anästhesiesystem bei dem sich der Patient in einem geschlossenen Regelkreis befindet. Ein Grund dafür liegt darin, dass in den publizierten Arbeiten Aspekte des klinischen Alltages wie Fehler und Messartefakte, die eine Regelung arg beeinträchtigen können, oft ausgeblendet werden. In der vorgelegten Arbeit befassen wir uns mit gerade diesen Problemen. Wir subsummieren diese Fragestellungen unter dem Begriff Supervisorfunktionen.

Bevor allerdings diese Supervisorfunktionen behandelt werden, werden zwei Grundvoraussetzungen diskutiert. Dabei handelt es sich einerseits um eine Hard- und Softwareplattform, die es erlaubt, Regelalgorithmen und die Supervisorfunktionen zu implementieren und im Operationssaal einzusetzen. Nach unserer Auffassung muss die Fehlerbehandlung beim Systementwurf beginnen. Deshalb wird spezielles Gewicht auf die Auswahl der Plattformkomponenten und den Softwareentwurf gelegt. Die Softwarestruktur orientiert sich stark an der spätern Erweiterbarkeit des Systems. Als zweite Grundvoraussetzung wird ein mathematisches Systemmodell entworfen, das die dynamischen Zusammenhänge zwischen den Eingangsgrössen Anästhesiegas im Frischgas und chirurgischer Reiz und den Ausgangsgrössen inspiratorische und exspiratorische Anästhesiegaskonzentration sowie dem mittleren arteriellen Blutdruck beschreibt. Dazu wird zuerst eine detaillierte Zusammenfassung der benötigten physiologischen Grundlagen geliefert und darauf werden die Modellgleichungen schrittweise entwickelt. Die Modellierung wird durch die Bestimmung der Modellparameter und einige Validierungsexperimente abgeschlossen.

Der Entwurf von Regelalgorithmen selbst ist kein eigentlicher Schwerpunkt dieser Arbeit. Es werden deshalb Regelalgorithmen übernommen, die von Marco Derighetti in seiner Dissertation entworfen wurden und für die klinische Validierung angepasst. Für einen beobachterbasierten Zustandsregler für die endtidale Anästhesiegaskonzentration und für einen Blutdruckregler mit endtidalen Override-Reglern werden Resultate einer umfangreichen klinischen Validierung vorgestellt. Motiviert durch die begrenzte Fähigkeit der Blutdruckregelung grössere Störungen zu kompensieren wird ein Regler basierend auf einer Störgrössenantizipation vorgeschlagen.

Für die Supervisorfunktionen wird zuerst eine Struktur entworfen, die alle in der Literatur postulierten Funktionen beinhaltet. Einzelne dieser Funktionen werden dann eingehender behandelt. Zuerst wird eine elegante Möglichkeit aufgezeigt, wie die beobachterbasierten Zustandsregler insensitiv gegen Messartefakte gemacht werden können. Sie basiert auf einer nichtlinearen Gewich- 
tung der Ausgangsrückführung im Beobachter. Die Stabilität dieses Verfahrens wird analysiert und mehrere Beispiele erfolgreich unterdrückter Artefakte werden gezeigt. Ein grosser Teil der Arbeit befasst sich dann mit der fehlertoleranten Regelung. Wir folgen einem Entwurfsverfahren, das von Prof. M. Blanke in Aalborg entwickelt wurde und gelangen dadurch zu einer Realisierung, die die schwerwiegendsten Systemfehler handhaben kann. In diesem Zusammenhang wird das Konzept "recoverability" entwickelt, welches es erlaubt zu beurteilen, wie weit ein fehlerhaftes System seiner ursprünglichen Funktion gerecht werden kann. Zum Schluss wird für die Bedienung des Systems eine Benutzerschnittstelle entworfen. Benutzerschnittstellenfragen sind in diesem Zusammenhang wichtig, weil eine klare Benutzerschnittstelle die Sicherheit eines Systems erhöht.

Neben verschiedenen originären Beiträgen besteht der Hauptbeitrag dieser Arbeit darin zu zeigen, dass mathematische Prozessmodelle auch in einem medizintechnischen Umfeld zur Behandlung von Fehlern herangezogen werden können. 